\title{
Ethics of Care: A Panacea to the Niger-Delta Crises.
}

\author{
N.M. Eribo and M.A. Izibili, Ambrose Alli University, Nigeria
}

\begin{abstract}
:
This paper examines the relevance of 'ethics of care' in the furtherance of a harmonious relationship between the Federal government, multi-national oil companies with the indigenous communities in the Niger-Delta region of Nigeria. The paper is of the view that when the 'ethics of care' is properly applied to the Niger-Delta conflict and communal eruptions that is currently threatening the unity of Nigeria on one hand, and her image internationally among committee of nations on the other hand, it is in our considered opinion that the 'sun of hope will beam' on the wretch region once more. By extension, normal activities of peaceful co-existence between the trio i.e the Nigerian government, the various multi-national oil companies and the indigenous people, will again flourish in the region. Then tolerance, agreeable relationship that fosters mutual co-existence and cooperation toward sustainable development of the area would have come to stay. The paper concludes that communal conflict in NigerDelta will be greatly reduced and sufficiently managed by the incorporation of the ethical principles, which constitute the 'ethics of care'.
\end{abstract}

Introduction:

Countries all over the world that are rich in natural resources ought to explore them for both material and human developmental needs of their people. This attest to the like of the advance nations of the word: The United States, Australia and Canada to mention but a few. This seems not to be the case of the developing Nations to which Nigeria is one. Ours is characterized by corruption, low human capacity of investment, slow economic growth, retarded economic reforms and weak institutional structures and government policies driven by exclusivism and repression among others. All of these constitute grand poverty and misery to our people. Hence, issues of restiveness among the populace, i.e. people of Niger-Delta tends to dominate part of the burning matters arising for discussions both internally and even externally. Its disturbing nature attracts more attention on political and economic sphere of the country.

This experience analyzed above, characterized the situation of the Niger-Delta communal eruption that is now threatening the continual existence of lives in the region on one hand and the entire Nation Nigeria on the larger scale. It is this same feeling of exclusion and suppression which the militant youth face in Niger Delta areas that informed the formation of an aggressive movement in the region to showcase their disenchantment, bitterness and long neglect culminates in hostage taking and consequently warring in the region hitherto regarded to as the 3rd largest 'Wetland of Wealth'. Unfortunately, the situation in the Niger-Delta presents a picture that shows the absence alternative means of addressing the issue of exclusionism in the likeness of lack of sustainable development, insecurity, environmental degradation and total 
negligence to the plight of the inhabitant of Niger-Delta areas. Prominent among the gross lack of comfort is the case of massive unemployment, lack of good health care delivery system, and total absence of social amenities that could make life meaningful for the Niger-Deltans. For this unhealthy development to be addressed adequately, the responsibility falls on both the government and the multi-national oil companies who are foreign investors in the region as well as the indigenous who owe the moral duty to making the environment enabling enough for the much talked about development.

\section{The Niger-Delta: Necessary background information}

For the purpose of clarification and understanding of the Niger-Delta crises, there is need for us to identify the part in Nigeria, which belongs to the Niger-Delta in the map or landscape of Nigeria as a country. This could be done either by geographical means, geopolitical means or by administrative convenience.

By geographical definition or demarcation, the area that make up the Niger-Delta as it was captioned in the Daily Champion of Wednesday the eightieth day, August 2001:13,

Critics of the definition of Niger-Delta based on political administrative structure argue that the Niger-Delta should be defined geographically as a triangle, with its apex between Ndoni and Aboh descending eastwards to the Qua Iboe River at Eket and westwards to the Benin rivers with its base along the Atlantic coast between the bights of Benin and Biafra ${ }^{1}$.

This means that the Niger Delta by geographical configuration, stretch from Ndoni to the Bight of Benin in Edo State. While the political and administrative tabulation of what constitutes the area called the Niger-Delta is according to Programme on Ethnic and Federal studies that: "The Niger- Delta zone constitutes the main center of Nigeria's oil industry, with three distinct ecological zones namely: the sandy coastal area, the freshwater swamp area, and the dry land rain forest" 2 . These areas politically speaking comprise the south-south geo-political zone of Nigeria consisting of six states and they are: Akwa-Ibom, Bayelsa, Cross-river, Delta, and Edo, Rivers States of Nigeria.

Finally, when we configure what constitute Niger-Delta from the report of Willink's Commission as to what make up the Niger -Delta based on the discovery of oil i.e. areas that actually house oil in Nigeria as Daniel Omoweh asserts, "The Niger-Delta properly comprises of Bayelsa Delta and Rivers states, and possibly, Akwa Ibom Since oil has become the determining factor" ${ }^{3}$. To this end, such states as: Edo, Ondo, Cross rivers, Abia and Imo are to be added to consist of Abia, Akwa Ibom, Bayelsa, Cross River, Delta, Edo, Imo, Ondo and Rivers in our today Niger -Delta region. In terms of population Daniel added that: 'The Niger -Delta has been estimated as having a population of about 20 million, with about 50 ethnic groups, and over 3,500 communities who speak not less than 260 dialects"4.

Besides, the Niger-Delta is noted in international communities as the third largest wetlands in the world with fresh and blackish water and mangrove swamp forest. 
The region is said to be rich is other natural resources like palm oil, herbal plants and kernel while animals i.e. wild life like reptiles, monkeys, lion among others are found in the thick forest. The major occupation of these people in ancient time were farming, fishing and braze smiting and the production of local gin. Events perhaps, have over taken this ancient occupation of the people as majority who would have loved to sustain the temple of farming, no longer have the land for this purpose. The reason being that oil explorers have polluted the land thereby making it unfertile for cultivation.

\section{Niger-Delta Conceptualized}

For the purpose of limiting the scope of this paper there is need for us to conceptualize the Niger-Delta so that we might be able to find a boundary to the context of our writing on the Niger-Delta communal crises and eruption with its attendant hostage takings and upheavals in the region. When we take up the challenge to conceptualize the Niger-Delta, we see a people whose cultural autonomy and ways of life have been devastated; their development has been hampered. To this end, the Ijaw youths affirmed that, " but for the economic interest of the imperialists, the Ijaw ethnic nationality would have evolved as a distinct and sep rate sovereign nation, enjoying undiluted political, economic, social and cultural autonomy were it not be the activities of the oil multi-nationals that came to balkanize their unity"5.

This means that their very substance has been distorted through the creation of new states by boundary adjustment and the siege of their land and cultures through policing and militarizing. Even the multi-national companies are not left out of this crusade of the Federal Government of Nigeria in state creation because what they, (the oil companies) are concerned about is the profit which they are to repatriate home as dividend of their investment without caring for the people. While the pollution of the environment where they make the profit is none of their concern with observance of known international standard. The Urhobo Foundation first economic summit gave an attestation to this thus:

The oil companies are paying lip services to the issue of environmental pollution and degradation and in collaboration with government have created opportunities for disunity among ethnic groups in oil producing areas. The oil companies have been more interested in hand outs and not partnership. They stay aloof as government enslaves the oil producing area. The situations in Ogoini and Ijaw lands are signals to the government and the oil companies about the urgent need to redress the marginalization of the oil producing communities ${ }^{6}$.

The Niger-Delta communities contribute immensely to the economy of Nigeria. Unfortunately, the Federal Government and oil companies do not reciprocate the friendly disposition of the host communities. Hence, despite the wealth of the land they have nothing to write home about the enormous wealth tapped from the land 
by the oil multinational companies. This has been identified as one of the reasons for youth restiveness in the area. In support of this statement, the Oron bill of right says: " Although the Oron nation has played host to oil exploration and exploitation activities, which started with shell in 1958 with capped wells dotted across the Oron landscape, there is nothing to show for it"?.

The Niger-Delta has lost her cultural and political autonomy. In their demands the Ogoni people of the Niger-Delta stated categorically as follows:

The Ogoni people should be granted political autonomy to participate in the affairs of the Republic as a Distinct and separate unit by whatever name called, Provided that this autonomy guarantees the Political control and use of fair proportion of Ogoni economic resources for Ogoni development: adequate direct representation as of right in all Nigerian national institutions; the use and development of Ogoni languages in Ogoni territory; the full development of Ogoni culture the right of religious freedom and the right to protect Ogoni environment and ecology from further degradation $^{8}$

This was met with mix feelings by the then government headed by late Gen. Sani Abacha, and resulted a case treasonable felony i.e. crime against the state which consequently led to the killing of Ogoni Kinsmen by the Federal Government of Nigeria. This shows how the government has suppressed the Niger-Delta people by state machinery to subvert their rights and aspirations as a people in the fulfillment of their destiny legitimately.

Suffice it to say here that in conceptualizing the plights of the Niger-Delta people, one is left to configure them on issues relating to injustice against communities in the area; serious grievances of critical concern- exclusion, deprivation, despoliation and fundamental problems of Human Rights Violation, oppression, intimidation and domination amongst others, etc. These unpalatable scenarios as experienced in the region forms the springboard that necessitate the Niger-Delta people to fight for their right to self determination even when it means laying down of their lives.

\section{Youth Militancy and Ethnic Movement}

The Niger-Delta has witnessed significant levels of protest by indigenous people. This is against the backdrop of resource-exploitation activities by the multinational oil companies in their traditional homelands and the government repressive and lackadaisical attitude towards their plight in form of lack of sustainable development in the rich wetland.

The indigenous people have also been spotted from time to time, also carried out violent attacks against properties and personnel of the oil companies, while recent development has led to incidence of hostage takings on foreign nationals, who are expatriate employees of the multinational oil companies in the wetland region. We have also witnessed in some of these violent clashes between state security forces and 
indigenous groups negative effects arising from gun shots and sub marine guns that have led to death the of thousands of people both the militant groups and members of the state security forces.

There are reported cases of women in Choba, Ogoni and Odi, who were raped by soldiers sent to savage the situation. This act of government using security men to suppress the indigenous people informed the formation of militant groups by the Niger-Delta people. Some take the form of ethnic or communal group movement. Example are the Ogoni People's Congress, (O.P.C.); Oron People's Movement (O.P.M); Movement for the Survival of Ogoni People (MOSOP); I.N.C. i.e. The Law National Congress (I.N.C. ); The Itsekiri National Association; The Urhobo Progressive Union (UPU) and Oron Development Union (ODU), to mention but a few. Their objectives were to crusade against oppression, demand for social change and the preservation of their right to life and significance.

\section{The Government Intervention}

The government has not folded it hands since the upheaval in Niger-Delta. It has instituted policies in two ways to create peace in the area thus: by instituting Developmental Agencies and by creating Conflict Management Strategies, among others. But, these methods seem not to have helped matters. Still the tension and aggression by the militant youths have increased drastically leading to massive destruction of properties and human lives in the areas. Arguably, the said methods by which government has intervened to solving the upheaval in Niger-Delta seem to be loop-sided rather than mutual, hence the defectiveness of the two methods.

The institutionalization of agency: In about 1957, the colonial government recognize the peculiar problem of the Niger-Delta and therefore instituted the Willinks Commission on 26th September of the same year to make recommendations for the development of the Niger-Delta Area. The commission failed to realize it mission as it could not meet the expectation of the indigenous people. Subsequently, the recommendations of the moribund commission gave birth to the establishment of the Niger- Delta Development Board (NDDB) in 1962. This board also failed as a result of the outbreak of the civil war that lasted for about three good years.

Some years later, the Federal Government initiated the oil mineral producing Areas Development Commission (OMPADEC) IN 1992. This commission was to use 3 percent of the total money accrue for Federal account from oil mineral products for the development of the oil rich areas; by quota of production to inject product and social amenities in the oil producing communities. But this commission also met its water loop as it was said to be a fraud on the part of the Federal government.

In 1998, a panel seeking the right strategy for the development of the Niger-Delta was initiated which prompted the then president Olusegun Obasanjo to embark on tour of the wretched area promised to give the people and the communities a face lift as he was said to have expressed a shock over the deplorable state of the area since he left the office in 1979 as the Military Head of State. Former President Obasanjo, on assumption of office approved the bill of the formation of the present Niger-Delta Development Commission (NDDC) that is currently vested with the responsibility of 
providing alternative options to the development of oil producing communities of the Niger-Delta Area.

Policies on revenue allocation and Fiscal sharing: At independence the government used 50 percent derivation principle of the derivable resource of the area for the development of the said areas but this was not free of fraud as the Okigbo Commission and Aboyade Technical committee faulted this principle. This principle was later suspended amid wild protest, which reverted it to 1 percent in the then second Republican government.

During the military era, under the president Ibrahim Babangida, the policy was abrogated and the principle of derivation was increased from 1 percent to 1.5 percent. It later went up to 3 percent until when Abacha took over, it was increased to 13 percent as part of the fall out of the national confab. The 1999 constitution validates this increment till date.

In a nutshell, despite all these public policies and strategies by government to stop the Niger-Delta crises all is to no avail because of the serious oppressive loop sidedness of all the so-called policies and strategies. They are turned out to be servicing the interest of the government and their neo-imperialist investors by name multinational companies at the detriment of the rightful owners of the land i.e the indigenous people. Paulo Freire accurately describes this phenomenon thus:

Paulo Fireire described how whole populations could be imprisoned in a culture of silence by structures clearly meant to keep them inarticulate. In Freire's description, power elites treat the masses as an object and do not expect to hear any original articulate word from them. Even further these elites try to control the very naming of the world in a way that abolishes any language that might expose the true situation of oppression if the popular masses seem about to break their submissive silence, the power elites uses whatever means they can to suppress such attempt including violence9.

The Niger-Delta masses have failed to keep silent in the midst of government and multinational companies' corruption, oppression and ecological degradation of the Niger-Delta area. This shows how the Nigerian government reacts to the demands of the Nigeria-Delta people. The fact must be agreed upon that some splinter groups of youth militants or militias do use violence in confronting the state, but even in these cases government initiated the move to violent eruption which create cycles of violence through out the regime. It is worthy of note here to say that those who make peaceful change impossible make a violent change inevitable. This is the precise state of mind of the Niger-Delta populace.

Between 1993-1995, Ken Saro-wiwa and the Movement for the Survival of the Ogoni people (MOSOP) were strong in the criticism of the oil multinationals and the government. The government in retaliation invaded Ogoni land imposing repressive measures and after an unjust trial before a special military tribunal, Saro-Wiwa and 
nine others were extra-judicially murdered on 10 November 1995.

The December 11, 1998 meeting of the Ijaw youth at Kaliana led to the formation of the Ijaw Youth Council, which proclaimed the Kaiama Declaration on 28 December the same year led to the Ijaw Youth Declaration of operation "climate change". This declaration brought about peaceable demonstrations by the Ijaw youth. The government retaliated by sending heavy-handed security men to Yenogoa; this created violent confrontation over some days that resulted to the death of numbers of youth and about three (3) soldiers. In this case, it was reported that the main reason for the statement was the official unwillingness of the government to dialogue with the Ijaw people over the wealth of their own land. Yet, a similar occurrence happened at a place called Odi were one of the gruesome massacres was recorded. The NigerDeltans woke up that early morning to witness killings of some policemen keeping watch at Odi junction by slimily unidentifiable people condemned the occurrence but the government in enemy invaded Odu by armed troops with armored tanks. By the end of the saga the whole town of Odi was leveled down leaving nothing alive.

There are so many other incidences where soldiers and armed policemen are deplored to guard oil facilities and at last leads to massive killing of innocent people who in their bid to protesting the ecological devastation of their land by the oil companies. This seems that the government so much have value for the profit from oil than the lives of the people massacred.

"The Nigerian government has a bundle of a set of unjustified laws like the petroleum Decree 51 of 1969, the offshore oil Revenue Decree No. 9 of 1971, the National inland waterways Authority Decree No. 13 of 1977, the land use act of 1978, land (Title vesting etc) Decree 52 of 1993, exclusive legislative list in the constitution"10. These laws are only means of suppressing the Niger Deltans. With these unjust laws that Nigerian government could be said to have failed in her goal to protect the lives and properties of his people as contained in the constitution of the Federal Republic of Nigeria. To this end Peter Ekeh correctly wrote:

Sadly, the Nigerian affairs compel us to separate the
Nigerian nation from the monster that has emerges as the
Nigerian state. Increasingly, the Nigerian nation is being
victimized by the Nigerian state Indeed, in the Niger-Delta
the Nigerian state is Waging war against a fragment of the
Nigerian nation; the Nigerian state has stolen the lands and
resources of the people with these resources It now recruits
foot soldiers in its immoral campaign against the Nigerian
nation ${ }^{11}$.

It is a sad experience to see a state that suppose serve his citizenry is in connivance with foreign nationals all because of profit from oil facilities: Instead of mediating between the Niger-Delta indigene and the oil multinational companies in issues of crises, the government decides to take side with the multinational oil companies against her people who are the landlord of the land where the crude oil is explored. 


\section{An Eagle's Eyes Views On Niger Delta Crises}

The government of Nigerian through the publication by the Federal ministry of information and culture has a contra view about the matter arising in Niger Delta crises which the publication tagged "The truth of the matter." In this book; "The Nigeria Ogoni crisis: The truth of the matter", we are made to understand that at the beginning of the interrelationship between the shell petroleum development company with the Ogoni people as a Microcosm of the macrocosm in the Niger Delta crises, there was amiable relation until when some hungry lions among the indigenes started forming militant group in the disguise of youth movement. For example the national youth council of the Ogoni people founded and headed by Ken Saro-wiwa, the purported ill death sentenced Ogoni man as detracting from some member of Nigerian communities and the United Nations that the death sentence of Saro-wiwa and nine others was against standard human rights and acceptable International judicial practice, while the other view said they were hanged because of their supposed demand for the protection of their environment from degradation. But against popular claim is the belief by the government that these claims are far away from the truth.

The Ogoni issue to the government is much more complex than we can believe. The issue goes beyond environmental protection or human right activism. To this publication, the Ogoni land crisis in the Niger Delta as one of the oil producing areas in the Niger Delta shown an aftermath of series of crisis which include, inter-communal strives, the height of which involved series of murder cases and in particular the murder of Ogoni chiefs by the militant youth formed by Ken Saro-wiwa. We are made to understand from this publication that the major problem surrounding the Ogoni crisis is miss information either by the media or through verbal means; all were distortion of the facts about Ogoni land, as this Federal publication holds.

This means that the government according to this publication is saving face and running away from the real fact about the happenings in the Niger-Delta. Thanks to the new regime under the leadership of president Musa Umaru Yar'adua; who is making frantic effort to end the upheaval in the Niger-Delta. To ensure the effort of this new regime does not end in Fiasco as the various efforts of previous regimes in ending this worrisome act; come the thrust of this paper becomes an imperative need. The need to apply ethics of care in the relationship between the trio i.e. the Federal government the oil multinational companies and the indigenous people of Niger Delta who reside in the rich wetland region.

The inter relationship between the trio must as a fact of necessity be well catered for in such a way that it become harmonious, peaceful and orderly such that the wetland becomes habitable by all dwellers, so that greed, hatred, disenchantment, disaffection and principally, full blown war, will all become a thing of the past in the Niger Delta area.

\section{What is Ethics?}

Just like philosophy its self, ethics has no one sentence definition; but etymologically, ethics (ta ethica) is derived from the Greek gender adjective ethikos, which means custom or way of doing things in a society. That is, it is the approved norms and habits of particular society. Ethics therefore, indicates the dos and don'ts in a given society. 
Jacque Maritain defined ethics thus: "The practical science, which aims at procuring men Unqualified good, his absolute good. It is in the strict Sense the science of action, the science of human acts"12.

The ultimate goals of ethics are human perfection, the good life; as it relates to human acts in relation of human another in human society. Human society will know no peace where there is no rule of conducts. Hence for the sake of peace and harmony in human society there is need for code of conduct which shows the ways by which man is to relate with one another in one hand and men with other i.e. the lower forms of life in the environment.

It is at this sphere that ethics become important in human society hence the imperative of 'ethics of care' in Niger Delta in deciding right mode of conduct among the trio in the region and how they ought to relate with one another in order that harmony will prevail; there is need for rule of conduct among the trio for the regulation of right conduct in the wetland.

\section{Ethics of Care as a Model}

When we talk of ethics of care as a theoretical formulation; we are talking about 'ensuring safety of lives and property in the wetland: caring for and about all human i.e. life forms in Nature. Life is it said is sacrosanct i.e. sacred and no one has the right to take up except God the maker. Iroegbu commenting on the value of life said: "Life is the basis of all goods; it is necessary source As well as condition of every human activity and Of all society... life is a gift of God and we should Be able to accept it will full responsibility and dignity"13.

Care requires that we be sensitive to the needs of all life forms both humans and the lower forms i.e. the non-humans. This requires that we see others as existence and respect them as their existence is in relation to ours without which life itself, is incomplete. The self and others most be seen as an organic whole. This means that all life forms and non-life forms most of necessity be appreciated, used and developed. We have to keep our common humanity in mind: through tolerance, sympathy, patience and hospitality in our relationship with one another as humans in one hand, and human with non -humans in the other hand. 'Ethics of care' is best expressed and understood in four ways: Non- malevolence principle; The benevolence principle; The utilitarian bases of care; and The principle of Justice.

The principle of non-malevolence: "Above all, do not harm" as the most famous and most quoted of all moral maxim in moral philosophy. This principle can be formulated in various ways but here is one relatively non-controversial way of starting: "we ought to act in ways that do not cause needless harm or injury to others" The principle tells us that we have a duty to avoid malevolence- that is, to avoid harming or injuring other people. In human daily activities, we violate the principle of no malevolence when we intestinally do something we know will cause someone harm or on the positive, we do not cause harm on them.

The principle of beneficence or benevolence: This is another moral principle that animate are explains the ethical principle of care which says "As to humanity, make a habit of two things- to help or at least to do no harm" The directive from the ethics of care' states that humans has two duties. "At least to do harm" which is in connection 
with the principle non-malevolence" i.e "to help" which is in connection with the principle of beneficence or benevolence as the case may be. The principle can be stated as: We should act in ways that promote the welfare of other people. That is we should help others people when we are able to do so.

The principle of utility: The principle of utility which can be formulated this way: we should act in such a way as to bring about the greatest good in such a way as to bring about the greatest benefit and the least harm. This principle is the very foundation of the moral theory utilitarianism, which found it bearing in the 'Ethics of care'

The principle of justice: We expect to be treated justly in our dealings with others and with institutions. If we are faced with a critical situation which requires us to apply wisdom i.e. justice our own personal detriment we most be able to discharge equity even at a cross road in our daily experience. It ought to be so, but the fact is that we do not always expect that being treated justly will work to our own advantage, which we most try to subordinate for justice to prevail.

These sub-principles which are the peculiarities of the 'Ethic of care' are very paramount in bringing about peace in the Niger-Delta in the relationship between the three occupants of the wetland in order to stop crisis and ethic or communal eruptions that has claimed lives and properties and the current hostage taking in the Niger Delta region.

\section{'Ethic of Care' as a solution to the Niger-Delta crises}

Upon these above principles which explicate the normative principles of care, we are convinced that when both trios i.e. the Niger-Delta people, the Federal government of Nigeria and the so called multinational companies who are the exploiters of the crude oil in the Niger Delta area if they could have a sense of belonging to make a step forward in the application and being obedient to the complimentary principles of Normal violence; and being beneficent or benevolent and above all exercise the act of creating the greatest benefit and acting in such manner as to bring about the least harm in their daily operations in the Niger-Delta such that justice prevails in their various social relationship with the people of the wetland, while the government on his part create an enabling atmosphere which help to preserve same conditions above then the moral or ethical principle of care will have been established.

The ethical principle of care of institutionalized in the social fabric of the relationship between the indigene of the wetland and the government on one hand and the multinational companies on the other hand in interacting with each other, caring for one another's needs and respecting one another's rights and promoting the indigenes' well-being in both policy decision and in material provision, the daily fracases and wars which characterized the Niger-Delta region will come to an end: The imbalance in social relations is one of the many reasons or underlying factor to social upheaval, but when there is 'profound care' far the needs of the indigenes then the relationship between them will becomes symbiotic. Such mode, which will make each having no regret, will bring in a new sphere of harmony, peace and tranquility. It will then be well with both humans as well as the environment: because both humans and the non-humans are being cared for. The 1996 catholic Bishops' Conference held 
in England and Wales summed this up thus:

\begin{abstract}
Our environment common good are not only available far careful use and enjoyment today, but are held in trust for use and enjoyment of future generations. Public authorities must not treat them as having no intrinsic worth, nor commercial concerns see them merely as sources of profit or loss. The environment as well is a great repository of humanity, present and future, freely and equally ${ }^{14}$.
\end{abstract}

The environmental issues in the Niger-Delta have reached on alarming proportion in recent times, issues such as ecological degradation in the like of oil spillage, infertile Agricultural land, river pollutions, air pollutions and gas flaring that contributes to excessive heat and the emission of carbonated gasses that are deadly to human health call for public attention, the multinational companies and the government.

Hence 'care' is a needed panacea that will erode all kinds of man inhumanity to man in the operational social relations between the owners of the wetland and the socalled infiltrators into the land. There is need for securing man and his environment in the Niger-Delta region.

What constitutes environmental and human insecurity in the Niger-Delta is the destruction of ecological support system for a continued life, which is traceable to anthropogenic impact on the environment. William Fox put this in the following way. "The world may end up in a big bang or a whimper, the big bang of the big bomb or the whimper of exhausted overloaded or poisoned life support system"15.

\title{
Conclusion:
}

Whether it is the Nigeria government that is fueling the crises in the Niger-Delta or the Militant youth or the Multinationals who are commercial profiteers, we are not here to pass buck but rather this paper is interested in seeking means to bring to an end the crises in the Niger-Delta through the cooperation of all stake holders in the region, by the normative principle of care with its axiomatic rules of non-male- volence, Benevolence, Utility and above all justice in the region in the relation between the trio on one hand and the environmental on the other hand. It is or considered opinion that when the parties involve realizes that they all need each other the simpler it will become for peace to reign in the region' called Niger-Delta.

\section{References and Notes}

1. See The Daily champion, Lagos, Wednesday, 8 August 2001, P.13

2. See programme on ethnic and Federal Studies (PEPS), the Niger Delta question: Background to constitutional Reform, P.E.P.S, Ibadan 2004, P.10

3. Omoweh, Daniel "Governance, Democratization and Development in the Niger-Delta, Background papers in Nyong, E.E and Oladipo (eds) proceeding of the international conference on the sustainable Development of the Niger Delta Region NDDC Port Harcourt, 2003, p. 12.

4. Ibid, P. 12

5. Ijaw Youths Kaima Declaration, available from http://w.w.w. waado.org/Niger Delta/ 
Rights. Declaration/Kaima Declaration htmc

6. Urhobo foundation, first urhobo Economic Summit (Communiquic) act 5. accessed 14 August 2007; available from

http//w.w.w; waado. Org/organizations uf/effirst Econ Summit html

7. Oron Bills of Rights or Article

8. The Ogoni Bills of rights Article 20

9 Paulo Freire, Cultural Action for Freedom. Cambridge: Harvard educational review, Monograph, Series 1, 1970 pp. 3-4

10. G,G. Darah, The Niger Delta Manifesto article online(Buffalo: urhobo Historical society, accessed 14 August 2007, http//w.w.wwaado org/Niger Delta Essays/ Politics in Niger Delta Manifestor. Darah.

11. Peter Ekeh, The mischief of History: Bala Usman's unmaking of Nigeria History (essay online Buffalo: Urhobo Historical Society, 2001 accessed 14 August 2007); available from http//w.w.w waado org/Niger Delta Essays Bala Usman / Mischief in history html.

12. Jacques Martain, An Introduction to Philosophy translated by E.I. Walkin (New York: Sheed and war. 1962) P. 196.

13. P.O. Iroegbu, Medical profession: Medical Oaths: statement and Analysis" in P.O. Iroegbu and A.O.Echekwube (eds), Kpim of Morality. Ibadan: Hieneman education book 2005. P. 533

14. Excert from common God: A statement by the catholic Bishops' Conference of England and Wales. 1996, reprinted by catholic Secretariat of Nigeria, Lagos. 1997, p. 107.

15. William, T. Fox, et.al., The Ethics of Environmental concern, Oxford: Blackwell, 1982, p.45. 